\title{
Generic Business Strategy as Driver of Competitiveness in Organizations: A Study of Selected Mobile Telecommunication Companies in Lagos, Nigeria
}

\author{
Onyeaghala Obioma Hyginus, Odiba Onyejeche Maria
}

Department of Business Administration, Federal University, Wukari, Nigeria

Email address:

onyexinvltd ayahoo.com (O. O. Hyginus)

\section{To cite this article:}

Onyeaghala Obioma Hyginus, Odiba Onyejeche Maria. Generic Business Strategy as Driver of Competitiveness in Organizations: A Study of Selected Mobile Telecommunication Companies in Lagos, Nigeria. Journal of Business and Economic Development.

Vol. 3, No. 3, 2018, pp. 86-96. doi: 10.11648/j.jbed.20180303.14

Received: October 8, 2018; Accepted: October 22, 2018; Published: November 27, 2018

\begin{abstract}
The telecommunication industry has witnessed great increase in the level of competition since its privatization in Nigeria. A lot of works has centered on strategies to make business perform, especially those operating in competitive environments.. But not much has been done in the area of generic business strategy and organizational competitiveness. This study was aimed at examining if generic business strategy can serve as a driver of organizational competitiveness. The survey research design was adopted. Primary source of data was used with questionnaire designed in five points likert-scale, ranging from strongly agree to strongly disagree. Cost leadership, product differentiation and focus strategy were the indicators measured by this study. Data was analyzed using frequency tables and simple percentage method. Formulated hypotheses were tested using the Karl Pearson Product Moment Correlation techniques. Cost leadership and organizational competitiveness were found to be positively correlated (at 0.718 ), the study discovered that product differentiation and organizational competitiveness has high positive relationship (at 0.922), the researcher found out that the relationship between focus strategy and organizational competitiveness is (at 0.80 .7 ) probability value. It was recommended that mobile telecommunication services providers should continue to take a lead of cost in an industry to achieve leverage over competitors, since cost leadership influences organizational competitiveness. In addition, product differentiation among other generic business strategies should be adopted because competitive leverage of an organization over other competitors to a great extent depends on it. Lastly, focus strategy can help organizations to achieve competitive leverage over other organization in the same industry.
\end{abstract}

Keywords: Generic, Cost Leadership, Differentiation, Focus, Strategy, Competitiveness

\section{Introduction}

To build a strong, viable and profitable business, it is necessary to develop a strategy. Essentially business strategy is the process that the organization takes to make decisions about the business direction; a plan that allows a business or organization to direct activities that are consistent with the goals of the business owner and the organization, and spend money wisely in order to create the greatest amount of return on investment. The essence of strategy is to achieve performance.

Organizations employ different types of strategy to develop competitive advantage and to perform, and generic strategy is one of them. Generic strategy is a broad and superior business level strategy which enables a firm to create value for its buyers and establish a sustainable and profitable market position. The strategies to provide this superior performance are: cost leadership, differentiation or focus strategy. The opinion of [2] was that the extent to which a firm is able to create a defensible position in an industry is a major determinant of the success with which it will outperform its competitors. Competitive strategy consists of all those moves and approaches that a firm has and is taking to attract buyers, withstand competitive pressure and improve its market position. A company has competitive advantage whenever it has an edge over its rivals 
in securing customers and defending against competitive forces [3].

The telecommunications industry in Nigeria, just like many other countries of the world has in the recent past been among the most competitive industry of the economy. The highly competitive landscape in the telecommunication today, compel operators to utilize competitive strategies that enable them grasp surprising opportunities, respond to threats and outmaneuver their rivals in order to endure and succeed [4].

These have resulted in greater attention to analyzing competitive strategies under different environmental conditions. Initially there were only two major players: MTN and Airtel. The current role calls of GSM operators consists of MTN, Airtel, Glomobile, Etisalat, Visafone, Nitel's M-tel, Multi-Links, Starcoms among others. The country's telecommunication industry was the largest contributor to growth in 2012, expanding by 34.2 percent. Telecommunication as a percentage of GDP was 7.05 percent in 2012, higher than financial services and manufacturing sectors [5]. Buttressing the growth in the sector the [6], says "investment in the telecommunication sector stands at five billion Naira". The entry of others operators made the industry very competitive, consequently, the growing competitive environment occasioned price wars which lead to the firms employing various competitive strategies to survive in the industry.

According to [1] the three generic strategies are required for different resources, organizational arrangements, control procedures, styles of leadership and incentive systems which could translate to improved organizational performance and competitive advantages. It was properly captured when [7] said that the ability to outperform competitors and to achieve above average profits lies in the pursuit and execution of an appropriate business strategy

\subsection{Statement of the Problem}

The Nigeria telecommunication sector witnessed a major revolution in 2001 with the granting of the Global System for Mobile telecommunication (GSM) license to providers. Today, the telecommunication industry in Nigeria is becoming more competitive may be because of the unprecedented growth and development recorded in the sector. Observably, these operators are searching for ways to compete effectively because each operator wants to increase its market share and make profit to enable it carry out its activities successfully. Perhaps, the growth in the industry may have triggered competition between the providers as each of them pursued strategies that are directed to enable them to have their own share of the market in order to be profitable and to survive [8].

It was [1] who said that superior performance can be achieved in a competitive industry through the pursuit of a generic strategy, which he defines as the development of an Overall Cost Leadership, Differentiation, or Focus approach to industry competition. Porter ibid maintained that if a firm does not pursue one of these strategy types, it will be stuck-in-themiddle and will experience lower performance when compared to firms that pursue a generic strategy. But it has been observed that some firms operating in a highly competitive industry hardly pay desired attention to or focus on the need to operate at low cost; in terms of low input cost, economies of large scale, product service design and low pricing. Many firms seem to ignore the provision of unique goods and services which provides high customer loyalty. In addition, some fail to narrow or segment the industry and serve a niche to the exclusion of others to achieve brand reputation. This makes one to wonder why these organizations are not mindful of generic strategy that can gives them results or if generic strategy has nothing to offer for organizations desirous of achieving competitiveness in their operation. This creates a research gap and it is in an attempt to fill the gap that this study was designed.

\subsection{Objectives of the Study}

The main aim of this study is to examine if generic business strategy is a driver of organizational competitiveness. The specific objectives are:

i. To examine if cost leadership influences organizational competitiveness,

ii. To investigate if product differentiation influences organizational competitiveness,

iii. To determine if focus strategy influences organizational competitiveness.

\subsection{Research Questions}

The following are the questions which this study attempt to answer:

i. Does cost leadership influence organizational competitiveness?

ii. Does product differentiation influence organizational competitiveness?

iii. Does focus strategy influence organizational competitiveness?

\subsection{Research Hypotheses}

The test hypotheses are:

$\mathrm{Ho}_{1}$ : Cost leadership has no influence on organizational competitiveness.

$\mathrm{Ho}_{2}$ : Product differentiation has no influence on organizational competitiveness.

$\mathrm{Ho}_{3}$ : Focus strategy has no influence on organizational competitiveness.

\subsection{Scope of the Study}

The study covered only the major mobile telecommunication service providing companies operating in Lagos State capital City, Nigeria.

\subsection{Significance of the Study}

This study would be of importance to the telecommunication service providing companies in Nigeria as they would be able to know how competitive strategies play a role in shaping their operations and at the same time 
they would know which competitive strategies to use in order to remain competitive.

The government as the regulator of firms in the industrial sector would benefit from the findings of this study. It will enlighten them on the various healthy competitive strategies that service providers can adopt and to create conducive environment for such. This is to say, information gathered through this study would help the policy makers to formulate policies beneficial to the telecommunication services providers. The results of this study would also be valuable to researchers and scholars, as it would form a basis for further research.

\section{Conceptual Framework}

\subsection{Overview of Business Strategy}

Strategy is the direction and scope of an organization over the long-term that provides advantages for the organization through its pattern of resources within a demanding environment [3]. Business strategy is defined by [9] as the long-term plan of action a company may pursue to achieve its goals. A business strategy is an overall plan of action which defines the competitive position of a firm. It is a well thought out plan which clearly articulates the direction a business will pursue and the steps it will take to achieve its goals. In fact it results from the goals established to support the stated mission of the business.

\subsection{Concept of Generic Business Strategy}

For a firm to adequately and promptly respond to competition successfully, it requires well-defined market oriented strategies [10]. In the words of [1], such strategies can enable a firm to create value for its buyers and establish a sustainable profitable market position. The strategies to provide this superior performance are: cost leadership, differentiation or focus strategy [11]. It was further explained by [1] that a firm may gain cost advantage through economies of scale, proprietary technology, cheap raw material, among others; while the strategy of differentiation can be used by offering a different product, a different delivery system, a different marketing approach, or by emphasizing different functional areas within the firm [10]. Firms can also offer a narrow range of products/services or target specific customers (focus).

Generic strategies can help the organization to cope with the five competitive forces (entry barriers, threat of substitution, bargaining power of buyers, bargaining power of suppliers and competitive rivalry) in the industry and do better than other organization in the industry. Generic strategies include 'overall cost leadership', 'differentiation', and 'focus'.

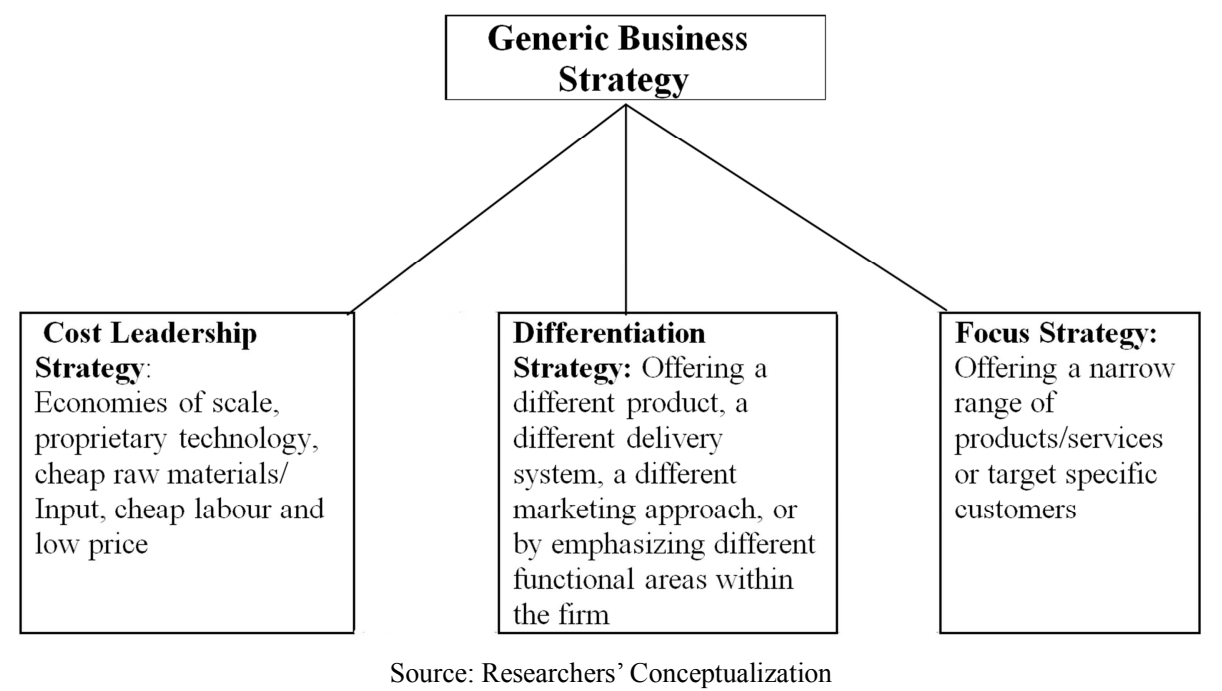

Figure 1. Generic Business Strategy Model.

\subsubsection{Cost Leadership Strategy}

Cost leadership involves becoming the low cost firm in an activity that can operationalize as low input costs, economies of scale, experience, products/process design and low pricing [13]. Low input costs involve locating operations close to materials and cheap labour; economies of scale require large scale operations and experience, this leads to efficiency. Products/process design influence efficiency by making products from cheap standard materials while low pricing is made possible by having products that are close to that of competitors in terms of features. The firm can then make small price cuts to compensate the slightly lower quality [13]. The low cost strategy should translate to a profit margin that is higher than the industry average [1].

\subsubsection{Differentiation Strategy}

Differentiation is also one of Porter's key business strategies [14]. Product differentiation involves tailoring the product or service to the customer. This allows organizations to charge a premium price to capture market share. As argued by [15], a differentiation strategy is often but not always associated with a higher price because it usually makes price less critical. When using this strategy, a company focuses its 
efforts on providing a unique product or service [16, 17]. Product differentiation fulfills a customer need since, the product or service is unique; this strategy provides high customer loyalty $[1,17]$.

\subsubsection{Focus Strategy}

Focus strategy is quite different from others, in that it aims at a narrow competitive scope within the industry. Focus is about segmenting the industry and serving the narrow niche to the exclusion of others [1]. Focus strategy has two variants- cost focus and differentiation focus. Cost focus aims at achieving cost advantage while differentiation focus is about seeking differentiation in a target segment. Cost focus exploits differences in cost behavior in some segments, while differentiation focus exploits the special needs of buyers in certain segments [1, 11]. As [12], put it, small companies; the better ones, usually thrive because they serve narrow market niches. Market focus allows some businesses to compete on the basis of low cost, differentiation and rapid response against much larger businesses with greater resources because focus lets a business "learn" its target customers, their needs, special considerations they want accommodated and establish personal relationships in ways that "differentiate" the smaller firm or make it more valuable to the target customer [12]. They contend that firms pursue only one of the above generic strategies but some firms make an effort to pursue more than one strategy at a time by bringing out a differentiated product at low cost. According to them, though approaches like these are successful in short term, but hardly sustainable in the long term and if firms try to maintain cost leadership as well as differentiation at the same time, they may fail to achieve either.

\subsection{What Organization Should Do to Achieve Generic Strategy}

Michael Porter identified the things an organization should do to achieving differentiation, cost leadership, and focus strategies. This is illustrated by the table below:

\begin{tabular}{|l|l|}
\hline Strategy & Organizational Characteristics \\
\hline Differentiation & $\begin{array}{l}\text { Acts in an organic, loosely knit way with, strong coordination among } \\
\text { departments. } \\
\text { Strong capability in basic research } \\
\text { Creative flair, thinks "out-of-the-box" } \\
\text { Strong marketing abilities } \\
\text { Rewards employee innovation } \\
\text { Corporation reputation for quality or technological leadership }\end{array}$ \\
\hline Cost Leadership & $\begin{array}{l}\text { Strong central authority; tight cost controls } \\
\text { Maintains standard operating procedures } \\
\text { Easy-to-use manufacturing technologies } \\
\text { Highly efficient procurement and distribution systems } \\
\text { Close supervision; finite employee empowerment } \\
\text { Frequent, detailed control reports }\end{array}$ \\
\hline Focus & $\begin{array}{l}\text { May use combination of above policies directed at particular strategic } \\
\text { target } \\
\text { Values and reward flexibility and customer intimacy } \\
\text { Measures cost of providing services and maintaining customer loyalty } \\
\text { Pushes empowerment to employees with customer contact }\end{array}$ \\
\hline
\end{tabular}

Source: [18]

Figure 2. Organizational Characteristics to Achieve Generic Strategy.

\subsection{Concept of Competitiveness}

Competitiveness otherwise called competitive advantage means to have an edge over competition. It is an advantage that exists when the firm is able to deliver the same benefits as competitors but at a lower cost. Competitiveness enables the firm to create superior products, superior profits and superior value for its customers and for itself.

Essentially, a competitive advantage answers the question, "Why should the customer purchase from this operation rather than from the competitors?" A key point to understand is that a venture that has customers for a reason, successfully growing a business is often dependent upon a strong competitive edge that gradually builds a core of loyal customers, which can be expanded over time [19], through the following; customer loyalty and brand reputation:

\subsubsection{Customer Loyalty}

Customer loyalty is allegiance or commitment a customer owes to an organization. It encourages consumers to shop more consistently, spend a greater share of wallet, and feel positive about a shopping experience, helping attract consumers to familiar brands in the face of a competitive environment [20]. There must be something inherent in a product or service that makes an organization to achieve customer loyalty. Thus sustainable competitive advantage measure entails both an attitudinal and behavioral tendency to favor one brand over all others, whether due to satisfaction with the product or service, its convenience or performance, or simply familiarity and comfort with the brand. 


\subsubsection{Brand Reputation}

Another sustainable competitive advantage is brand reputation. Brand reputation refers to how a particular brand (whether for an individual or a company) is viewed by others. A favorable brand reputation means consumers trust your company, and feel good about purchasing your goods or services. An unfavorable brand reputation, however, will cause consumers to distrust your company and be hesitant about purchasing your products or services. Today, companies shape their brand reputation with ease using traditional advertising and public relations; online reputation management helps to keep others from damaging companies' brand [21].

\subsection{Theoretical Framework}

This study is anchored on the following theoretical perspectives: The resource based theory and innovation profit theory.

\subsubsection{Resource Based Theory (RBV)}

The resource-based perspective has an intra-organizational focus. It argues that performance is a result of firm-specific resources and capabilities [22]. The basis of the RBV is that successful firms will find their future competitiveness on the development of distinctive and unique capabilities, which may often be implicit or intangible in nature [24]. The firm's unique resources and capabilities provide the essence of strategy. Arguing, [26] assert that if all the firms were equal in terms of resources, there would be no profitability differences among them because any strategy could be implemented by any firm in the same industry.

The RBV suggests that competitive advantage and performance results are a consequence of firm-specific resources and capabilities that are costly to copy by other competitors. Therefore, in an organization's effort to gain competitive advantage, it is important to establish the resources owned by the company and how such resources can be tapped for the given organization's competitive advantage. The resource-based view (RBV) is a basis for the competitive advantage of a firm that lies primarily in the application of a bundle of valuable tangible or intangible resources at the firm's disposal [23]. The RBV isolates unique resources that are complex, intangible, and dynamic within a particular firm which can be utilized by the firm to gain and sustain competitive advantage (Barney, 1991xx). The bundles of resources that are distinctive to a firm give it an edge which other firms may not easily copy hence providing sustainability of the competitiveness [24].

\subsubsection{Innovation Profit Theory}

Innovation profit theory which is a part of compensatory profit theories describes the above normal profits that arise following successful invention or modernization [25]. This theory revolves around the products a company offers and infers that organizations which produce highly differentiated goods and services tend to make above normal profits. Such compensatory profit theory describes above normal rates of return that reward a firm for extra ordinary success in meeting customer needs, maintaining efficient operations and so forth. Innovation is divided into two categories. The first type is those innovations that aim at reducing costs and the second category are those innovations aimed at creating demand. Costs can be reduced extensively by re-inventing the value chain and improving its efficiency. Demand for products on the other hand can be created through differentiation, customer service, increasing market share etc. Thus Profits are realized due to successful innovations where cost falls below the prevailing price of the product or the entrepreneur is able to sell more and at a better price than before. The profits in this case apply as long as the innovation is exclusive to the firm. Once other players manage to copy, and then the profits start dwindling.

\subsection{Review of Empirical Studies}

Some empirical works related to this study are those carried out by: [8, 26-28, 30, 31].

A study was conducted by [26] on "Business Strategies and Sustainable Competitive Advantage of Banks in Port Harcourt" to ascertain the relationship and possible effect of dimensions such as product differentiation, cost leadership and focus/niche strategy on measures such as brand reputation and customer loyalty. The study used the crosssectional overview, while simple random technique was adopted. Data were collected through the use of questionnaire and analysis was done using Spearman Rank Correlation order via Statistical Package for Social Sciences (SPSS) version21. It was revealed that a significant relationship exists between both variables (business strategies and sustainable competitive advantage). Based on the findings, the study recommends that organizations should take into cognizance the cost of production and should try to produce their products at the lowest cost possible, without compromising quality desired by their consumers; in addition organizations should engage in high technological changes and improvement so as to gain a competitive advantage and remain competitive over others.

Another study was carried out by [27] on the investigation of competitive strategies and its relationship with the performance of GSM network operators in Nigeria. The study used a cross-sectional survey research design and primary data were gathered with the aid of a questionnaire. The questionnaire was structured to elicit information from respondents. The Pearson Product Moment Correlation and Multiple Regression were the statistical tools used to test the formulated hypothesis at 5\% level of significance. The findings of the study indicate that there is positive statistical significant relationship between the combination of competitive strategies variables and the performance of the GSM network operators in Nigeria. Based on the findings, the study recommended that, managers of the four sampled GSM firms should move more towards specialization and the servicing of niche markets, rather than depend only on costleadership strategy.

In a study conducted by [28] on "Impact of strategic 
management on competitive advantage and organizational performance - evidence from Nigerian Bottling Company" The study examined the impact of strategic management on competitive advantage and organization performance in Nigerian bottling company using the resource based theory as its theoretical basis. Structured questionnaire was used to source data from respondents. The data collected were analyzed using both descriptive such as frequencies, percentages mean, standard deviation and inferential statistics of Chi-square and Analysis of Variance (ANOVA). The findings show that the adoption and implementation of strategic management practices like product differentiation makes the organization not only to be proactive to changes but also initiate positive changes that consequently leads to competitive advantage and sustainable performance. It was recommended that organization should continuously maintain, sustain and improve strategic management practices since it is an indispensable tool for business organization performance.

A research on "competitive strategies and improved performance of selected Nigeria telecommunication companies." Carried out by [8] which sought to explore how competitive strategies could be implemented for improved customer satisfaction, retention and loyalty. Three null hypotheses were postulated to test the relationship between lower prices and customer satisfaction, uninterrupted trunk services and customer loyalty, and customer complaint handling and retention. Survey research design was adopted to carry out the study. A structured questionnaire was designed and validated through the construct validity and tested for confirmation using the KMO measure of sampling adequacy. It was also made reliable using Cronbach's Alpha test. From the study, findings revealed relationship between competitive strategies (cost leadership) and customer satisfaction, retention and loyalty. The findings revealed that there is a relationship between competitive strategies, its constituents and performance of telecommunication companies. It was recommended that universal mobile telecommunication services (UMTS) operators should adopt the culture of competitive strategies since it can impact on their performance for achieving competitive advantage.

On the study carried out by [29], on "generic strategies employed by food and beverage firms in kenya and their effects on sustainable competitive advantage which aimed at establishing whether generic strategies were employed by food and beverage firms in Kenya for sustainable competitive advantage.

The research used a descriptive study design. The study population consisted of 138 food and beverage manufacturing firms in Kenya registered with the Kenya Association of Manufacturers (KAM) by 2011. The data was tested for central tendency and dispersion after confirmation of normal distribution by appropriate tests of normality. Since the sample size was 32 (over the minimum 30 required for statistical analysis), regression analysis was carried out and interpretation of results of tests of hypotheses done. The research showed that 56.2 percent of the firms embraced strategies of cost leadership and differentiation simultaneously while 25 percent were exclusively on cost leadership and 18.8 percent were exclusively using differentiation. Results from Pearson's rank correlation coefficient between the dependent variable $\mathrm{Y}$ and the independent variables X1 and X2 gave coefficients of 0.653 and 0.279 respectively which was an indication of positive correlation.

A study conducted on "Porter's Generic Competitive Strategies" by [30], findings basically show that, strategy is about two things: deciding where you want your business to go and how to get there. Result of the study equally shows that competitive advantage grows out of value a firm is able to create for its buyers that exceeds the firm's cost of creating it. Value is what buyers are willing to pay, and superior value stems from offering lower prices than competitors for equivalent benefits or providing unique benefits that more than offset a higher price.

\section{Methodology}

\subsection{Research Design}

This study adopted the survey research design with the use of questionnaire to collect data on variables of interest.

\subsection{Area of the Study}

The area of the study is MTN and Glo headquarters in Lagos State, Nigeria. The choice is that the two firms are keenly competing with each other head long in the industry and generic business strategy is a top management decision that only the headquarters have the available information that will help the research.

\subsection{Population of the Study}

The population of the study consists of top level managers of MTN and Glo, Mobile Telecommunication Company. According to the human resource department of both organizations, there are 55 and 84 respectively, which makes a total study population of 139 .

\subsection{Sample Size Determination and Sampling Techniques}

The sample size was determined using Taro Yamane sample size determination formula.

Using the formula, the sample size obtained from the population was 103, (See appendix).

Sampling Techniques; The Bourly's Proportional Sampling Technique was adopted for this study. This sample technique was considered appropriate since it gives the elements of each company equal chance of being selected. Therefore, elements were selected proportionally from each company giving a sample size of 103, (see appendix).

\subsection{Source of Data/Data Collection Method}

The study used the questionnaire as instrument for data 
collection. The questionnaire was designed using a Likert scale format that ranges between strongly agree to strongly disagree and was distributed to respondents.

\subsection{Validity and Reliability of Research Instrument}

This employed content validity to validate the research instrument and internal consistency reliability by calculating a statistic known as Cronbach coefficient alpha to establish the reliability of the research instrument.

Table 2. Reliability Result.

\begin{tabular}{lll}
\hline Variables & Reliability Index & No of Items \\
\hline Cost Leadership & 0.70 & 5 \\
Product Differentiation & 0.74 & 5 \\
Focus Strategy & 0.81 & 5 \\
\hline
\end{tabular}

Source: SPSSv23.
The above table indicates that the variables are reliable and the instrument is reliable given the index values above 0.60 as suggested by [32].

\subsection{Analytical Technique}

The responses to the questions on the questionnaire were analyzed using frequency tables and simple percentage method. The research hypotheses were tested using the Karl Pearson Product Moment Correlation (r) technique with the aid of Statistic Package for Social Science (SPSSv21). Appropriate interpretation and discussion was made according to the results of the hypotheses testing, stating whether the hypotheses would be accepted or rejected.

Decision Rule: Reject Null Hypothesis if P-value is less than $0.05(\mathrm{P}<0.05)$ and accept Null Hypothesis if $\mathrm{P}$-value is greater than $0.05(\mathrm{P}>0.05)$,

\section{Data Presentation and Analysis}

Table 3. Cost Leadership Influence on organizational competitiveness.

\begin{tabular}{|c|c|c|c|}
\hline Statement Two & Response Options & Frequency & Percent \\
\hline \multirow{6}{*}{$\begin{array}{l}\text { Cost leadership influence on organizational } \\
\text { competitiveness }\end{array}$} & Strongly Agree & 50 & $53 . .2$ \\
\hline & Agree & 26 & 27.7 \\
\hline & Undecided & 2 & 2.1 \\
\hline & Disagree & 7 & 7.4 \\
\hline & Strongly Disagree & 9 & 9.6 \\
\hline & Total & 94 & 100.0 \\
\hline
\end{tabular}

Source: Field Survey, 2018.

Table 3 above ascertain whether cost leadership influence respondents' organizational competitiveness 50 respondents (53.2\%) strongly agreed, 26 respondents (27.7\%) agreed, 2 respondents $(2.1 \%)$ were indecisive, 7 respondents $(7.4 \%)$ disagreed and 9 respondents $(9.6 \%)$ strongly disagreed.

Table 4. Product Differentiation Influence on organizational competitiveness.

\begin{tabular}{llll}
\hline Statement Six & Response Options & Frequency & Percent \\
\hline & Strongly Agree & 18 & 19.1 \\
& Agree & 30 & 31.9 \\
Product differentiation influence on & Undecided & 19 & 20.3 \\
organizational competitiveness & Disagree & 10 & 10.6 \\
& Strongly Disagree & 17 & 18.1 \\
& Total & 94 & 100.0 \\
\hline
\end{tabular}

Source: Field Survey, 2018.

Table 4 above shows influence of product differentiation strategy on respondents' organizational competitiveness, 18 respondents (19.1\%) strongly agreed, 30 respondents $(31.9 \%)$ agreed, 19 respondents $(20.2 \%)$ were indecisive, 10 respondents (10.6\%) disagreed and 17 respondents $(18.1 \%)$ strongly disagreed;

Table 5. Focus strategy influence on organizational competitiveness.

\begin{tabular}{llll}
\hline Statement Ten & Response Options & Frequency & Percent \\
\hline & Strongly Agree & 23 & 24.5 \\
& Agree & 29 & 30.9 \\
Focus strategy influence on organizational & Undecided & 19 & 20.2 \\
& Disagree & 9 & 9.6 \\
& Strongly Disagree & 14 & 14.9 \\
& Total & 94 & 100.0 \\
\hline
\end{tabular}

Source: Field Survey, 2018.

Table 5 above shows influence of focus strategy on respondents' organizational competitiveness, 23 respondents (24.5\%) strongly agreed, 29 respondents (30.9\%) agreed, 19 respondents $(20.2 \%)$ were indecisive, 9 respondents $(9.6 \%)$ disagreed and 
14 respondents (14.9\%) strongly disagreed.

\subsection{Test of Hypotheses}

$\mathrm{H}_{01}$ : Cost leadership has no influence on organizational competitiveness.

Analysis of Correlation

Table 6. Testing of Hypothesis One.

\begin{tabular}{llll}
\hline & & Organizational Competitiveness & Cost Leadership \\
\hline \multirow{3}{*}{ Organizational Competitiveness } & Pearson Correlation & 1 & $.718^{* *}$ \\
& Sig. (2-tailed) & & .000 \\
& $\mathrm{~N}$ & 94 & 94 \\
\multirow{3}{*}{ Cost Leadership } & Pearson Correlation & $.718^{* *}$ & 1 \\
& Sig. (2-tailed) & .000 & 94 \\
\hline
\end{tabular}

**. Correlation is significant at the 0.000 level (2-tailed).

Source: SPSS Result 2018.

On the first hypothesis, the correlation analysis in table under 6 above indicates a positive significance value $(r-$ value) of $0.718^{* *}$ and probability value (p-value) of 0.000 . This analysis results fails to support the acceptance of the stated null hypothesis since the $\mathrm{p}$-value is less than $0.05 \mathrm{p}=$ $0.000<0.05)$ significance value and therefore, uphold the alternative hypothesis. This implies that cost leadership has influence on organizational competitiveness.

$\mathrm{H}_{02}$ : Product differentiation has no influence on organizational competitiveness.

Analysis of Correlation

Table 7. Test of Hypothesis Two.

\begin{tabular}{llll}
\hline & & Organizational Competitiveness & Product Differentiation \\
\hline \multirow{3}{*}{ Organizational Competitiveness } & Pearson Correlation & 1 & $.922^{* *}$ \\
& Sig. (2-tailed) & & .021 \\
& $\mathrm{~N}$ & 94 & 94 \\
\multirow{3}{*}{ Product Differentiation } & Pearson Correlation & $.922^{* *}$ & 1 \\
& Sig. (2-tailed) & .021 & 94 \\
\hline
\end{tabular}

**. Correlation is significant at the 0.01 level (2-tailed).

Source: SPSS Result 2018.

On the second hypothesis, the correlation analysis in table under 7 above gives a high positive significance value (rvalue) of $0.922^{* * *}$ and a probability value (p-value) of 0.021 . Thus, because the $p$-value is less than $0.05(p=0.021<0.05)$ $\mathrm{r}$-value which is the minimum level of null hypothesis acceptance, the null hypothesis is rejected and the alternative hypothesis is accepted. This means that, product differentiation has influence on organizational competitiveness.

$\mathrm{H}_{03}$ : Focus strategy has no influence on organizational competitiveness.

Analysis of Correlation

Table 8. Test of Hypothesis Three.

\begin{tabular}{llll}
\hline & & Organizational Competitiveness & Focus Strategy \\
\hline \multirow{3}{*}{ Organizational Competitiveness } & Pearson Correlation & 1 & $.807^{* *}$ \\
& Sig. (2-tailed) & & .030 \\
& $\mathrm{~N}$ & 94 & 94 \\
\multirow{2}{*}{ Focus Strategy } & Pearson Correlation & $.807^{* *}$ & 1 \\
& Sig. (2-tailed) & .030 & 94 \\
\hline
\end{tabular}

**. Correlation is significant at the 0.01 level (2-tailed).

Source: SPSS Result 2018.

On the third hypothesis, the correlation analysis in the table under 8 above gives a high positive significance value (r-value) of $0.807^{* *}$ and a probability value (p-value) of 0.030 . Since the $p$-value is less than $0.05(p=0.030<0.05)$ $\mathrm{r}$-value which is the minimum level of null hypothesis acceptance, the null hypothesis is rejected and the alternative hypothesis is accepted. This signifies that, focus strategy has influence on organizational competitiveness.

\subsection{Discussion of Findings}

This study proposed that generic business strategy is not a driver of organizational competitiveness thereby throwing the researcher into the world of unknown for empirical 
discoveries.

To statistically do the above, Pearson Product Moment Correlation with the aid of SPSS was used to test hypothesis one and the researcher found that cost leadership has influence on organizational competitiveness. The relationship between cost leadership and organizational competitiveness has been found to be positively correlated (at 0.718 ) probability value, which implies that, the more an organization takes a lead of cost in an industry, the higher its level of competitive leverage over competitors and vice versa. This finding is in line with the findings of [8] that revealed a relationship between competitive strategies (cost leadership) and customer satisfaction, retention and loyalty.

On test of hypothesis two, the study discovered that product differentiation has influence on organizational competitiveness. A highly positive relationship (at 0.922) probability value has been statistically established between product differentiation and organizational competitiveness which means that; competitive leverage of an organization over other competitors to a great extent depends on its product differentiation among other generic business strategies. This finding agrees with [28] who found that adoption and implementation of strategic management practices like product differentiation makes an organization not only to be proactive to changes but also initiate positive changes that consequently leads to competitive advantage and sustainable performance.

For the test of hypothesis three, the researcher found that focus strategy has influence on organizational competitiveness. The relationship between the two variables has been statistically established (at 0.80 .7 ) probability value. This signifies that a focus strategy can help organizations to achieve competitive leverage over other organization in the same industry. This finding is in consonance with the finding by [27] which revealed that there is positive statistical significant relationship between the combination of competitive strategies variables and the performance of the GSM network operators in Nigeria.

\section{Summary, Conclusion and Recommendation}

\subsection{Summary of Findings}

The research reveals that cost leadership has influence on organizational competitiveness. This implies that, the more an organization takes a lead of cost in an industry, the higher its level of competitive leverage over competitors. It also reveals that competitive leverage of an organization over other competitors to a great extent depends on its product differentiation among other generic business strategies. The researcher also found out that a generic strategy of focus can go a long way to helping organizations to achieve competitive leverage over other organization in the same industry.

\subsection{Conclusions}

In conclusion, this study shows that there is link between business strategy and organizational competitiveness which is a contemporary issue in the field of strategic management. The ability of a firm to deliver the same benefits as competitors but at lower cost, enable the firm to create superior products. Furthermore, the ability of a firm to outperform competitors and to achieve above average profits lies in the pursuit and execution of an appropriate generic business strategy.

\subsection{Recommendations}

The following were recommendations based on the findings:

1. Mobile telecommunication service providers should continue to take a lead of cost in an industry to achieve leverage over competitors, since it influences organizational competitiveness.

2. Product differentiation among other generic business strategies should be adopted because competitive leverage of an organization over other competitors to a great extent depends on it.

3. Focus strategy can help organizations to achieve competitive leverage over other organization in the same industry.

\section{Appendix}

Taro Yamane statistical formula is shown as:

$$
\mathrm{n}=\frac{\mathrm{N}}{1+\mathrm{Ne}^{2}}
$$

Where: $\mathrm{n}=$ Sample size

$\mathrm{N}=$ Total population size

$1=$ Constant

$\mathrm{e}=$ the assume error margin or tolerable error which this is taken as $5 \%(0.05)$. [31].

Substituting the above population values into the formula:

$$
\begin{gathered}
n=\frac{139}{1+139(0.05)^{2}} \\
n=\frac{139}{1+139(0.0025)} \\
n=\frac{139}{1+(0.3475)} \\
n=\frac{139}{1.3475} \\
n=103
\end{gathered}
$$

The formula for Bourly's Proportional Technique is shown below: 


$$
\mathrm{nh}=\frac{\mathrm{n}(\mathrm{Nh})}{\mathrm{N}}[31] .
$$

Where: $\mathrm{nh}=$ Sample Size per division $\mathrm{n}=$ calculated Sample Size

$\mathrm{Nh}=$ Population per division

$\mathrm{N}=$ Total Population Size

Table A1. Proportional Sample Technique Determination.

\begin{tabular}{llll}
\hline S/No & Name of Company & Population of each Company & Number to Sample nh $=\mathbf{n}(\mathbf{N h}) / \mathbf{N}$ \\
\hline 1 & MTN & 55 & $103(55) / 139=41$ \\
2 & GLO & 84 & $103(85) / 139=62$ \\
TOTAL & & 139 & 103 \\
\hline
\end{tabular}

Table A2. Correlation Results for test of Hypotheses.

\begin{tabular}{|c|c|c|c|c|c|}
\hline & & $\begin{array}{l}\text { Organizational } \\
\text { Competitiveness }\end{array}$ & Cost Leadership & $\begin{array}{l}\text { Product } \\
\text { Differentiation }\end{array}$ & Focus Strategy \\
\hline \multirow{3}{*}{$\begin{array}{l}\text { Organizational } \\
\text { Competitiveness }\end{array}$} & Pearson Correlation & 1 & $718 * *$ & $922 * *$ & $807 * *$ \\
\hline & Sig. (2-tailed) & & 000 & 021 & 030 \\
\hline & $\mathrm{N}$ & 94 & 94 & 94 & 94 \\
\hline \multirow{3}{*}{ Cost Leadership } & Pearson Correlation & $718 * *$ & 1 & $623 * *$ & $399 * *$ \\
\hline & Sig. (2-tailed) & 000 & & 000 & 003 \\
\hline & $\mathrm{N}$ & 94 & 94 & 94 & 94 \\
\hline \multirow{2}{*}{$\begin{array}{l}\text { Product } \\
\text { Differentiation }\end{array}$} & Sig. (2-tailed) & 021 & 000 & & 002 \\
\hline & $\mathrm{N}$ & 94 & 94 & 94 & 94 \\
\hline \multirow{3}{*}{ Focus Strategy } & Pearson Correlation & $807 * *$ & $399 * *$ & $567 * *$ & 1 \\
\hline & Sig. (2-tailed) & 030 & 011 & 002 & \\
\hline & $\mathrm{N}$ & 94 & 94 & 94 & 94 \\
\hline
\end{tabular}

**. Correlation is significant at the 0.01 level (2-tailed).

*. Correlation is significant at the 0.05 level (2-tailed).

\section{References}

[1] Porter, M. E. (1985). Competitive Advantage: Creating and sustaining superior performance, New York. USA: Free Press.

[2] Porter, M. E. (2000). Location, Competition, and Economic Development: Local Clusters in a Global Economy; Economic Development Quarterly; in https://doi.org/10.1177/089124240001400105.

[3] Thompson, A. and Strickland, A. J., (2009), Strategic Management: Concepts and Cases, Irwin, New York.

[4] Oyedijo, A. I. (2013). Business Policy and Strategic management: An Introductory Text with Cases. Lagos, Nigeria: Strategic International Press.

[5] Business Day (2013). Nigeria Telecoms' Subscription Dips as Industry Growth Rate Slows.

[6] Nigerian Communication Commission (NCC) (2018), Growth in the Telecommunication Sector,Thursday Vanguard Daily Newspaper, October $4^{\text {th }}$

[7] Yoo, J. W., Lemak, D. J., and Choi, Y. (2006). Principle of Management and Competitive Strategies: Using Fayol to Implement Porter. Journal of Management History, 12(4), 94107.

[8] Waidi, A. A (2014) Competitive Strategies and Improved Performance of Selected Nigeria Telecommunication Companies. Journal of Entrepreneurship, Management and Innovation. 8(4).

[9] Alder (2011). Deception as strategy: context and dynamics Journal of Managerial 23 (3), 33-46.
[10] Mburu, M. (2009) Strategic Responses by Mwalimu Sacco Society Limited to Challenges of Competition, Unpublished $M B A$ project, School of Business, University of Nairobi.

[11] Porter, M. E. (1980). Competitive Advantage: Techniques for Analyzing Industries and Competitors, New York. USA: Free Press.

[12] Pearce, J. A. and Robinson, R. B. (2005). Strategic Management; Formulation, Implementation and Control. $9^{\text {th }}$ Edition. McGraw Hill, Irwin.

[13] Johnson, G., Whittington, R. and Scholes, K. (2011) Exploring Strategy Text and Cases 9th edition. Harlow, England: Pearson Education Ltd.

[14] Reilly, T. (2002), "Be a champion of the solution", Industrial Distribution, Vol. 91 No. 5.

[15] Aaker, D. (1984) Developing Business Strategies N. Y.: John Wiley \& Sons Inc.

[16] Porter, M. E. (1996). What is strategy? Harvard Business Review, 74 (6): 61-78.

[17] Hlavacka, S., Ljuba, B., Viera, R. and Robert, W. (2001) Performance implications of Porter's generic strategies in Slovak hospitals", Journal of Management in Medicine, Vol 15 No 1.

[18] Daft, Richard, L. (1997) Revealing the Nature of Management. $4^{\text {th }}$ Edition. The Dryden Press, Harcourt Brace College Publishers.

[19] Ehmke, C. (2008). Strategies for Competitive Advantage. Department of Agricultural and Applied Economics, University Of Wyoming.

[20] Hollensen, S. (2015). Marketing management: A relationship approach. Pearson Education. 
[21] Cabral, L. M. (2001). Stretching Firm and Brand Reputation. RAND Journal of Economics, 658-673 Vol. 3, No. 11

[22] Barney J (1991) Competitive advantage and performance of the firm in:

https://www.emeraldinsight.com/doi/full/10.1108/0309059071 0721718 .

[23] Prahalad, (1996) A resource based theory of the firm knowledge versus Opportunism https://www.researchgate.net/publication/215915547.

[24] Wernerfeit, B (1984), A Resource-based View theory of the firm in: https://www.jstor.org/stable/25072858.

[25] Mark Hirschey(2006) determination of firms' and industries' innovative activity and performance in: https://ideas.repec.org/h/eee/haechp/v1_129.html.

[26] Onuoha, C. and SandOlori, W. O (2017) Business Strategies and Sustainable Competitive Advantage of Banks in Port Harcourt. International Journal of Advanced Academic Research, Social \& Management Sciences Vol. 3, Issue 11.
[27] Olamitunji, D. (2015) Aggregate Analysis of Competitive Strategies among the Global System for Mobile telecommunication Operators in Nigeria. Journal of Resourcefulness and Distinction, Vol 10 No. 1.

[28] Olanipekun, W. D, Abioro, M., Akanni, L. F, Arulogun, O. O and Rabiu, R. O (2015) Impact of Strategic Management on Competitive Advantage and organizational performance evidence from Nigerian Bottling Company. Journal of Policy and Development Studies Vol. 9, No. 2.

[29] Stephen, L. M and David, (2014) Generic Strategies Employed by Food and Beverage Firms in Kenya and Their Effects on Sustainable Competitive Advantage. International Journal of Business and Management Review, Vol. 2, No. 6.

[30] Ritika, T. (2013) Porter's Generic Competitive Strategies. Journal of Business and Management Volume 15, Issue 1.

[31] Onyeaghala, H. O. (2017). Research Methods, Lecture Monograph. Department of Business Administration Federal University Wukari.

[32] Uma, S. and Roger, B. (2010). Research Method for Business, $5^{\text {th }}$ Edition, John Wiley \& Sons Ltd. 